\title{
Efficiency of Crude Protein Utilisation in Grazing Dairy Cows: A Case Study Comparing Two Production Systems Differing in Intensification Level in New Zealand
}

\author{
Martín Correa-Luna ${ }^{1, * \mathbb{D}}$, Daniel Donaghy ${ }^{1}$, Peter Kemp ${ }^{1} \mathbb{D}$, Michael Schutz ${ }^{2}$ and \\ Nicolas López-Villalobos ${ }^{1}$ (D) \\ 1 School of Agriculture and Environment, Massey University, Private Bag 11-222, Palmerston North 4410, \\ New Zealand; D.J.Donaghy@massey.ac.nz (D.D.); P.Kemp@massey.ac.nz (P.K.); \\ N.Lopez-Villalobos@massey.ac.nz (N.L.-V.) \\ 2 Department of Animal Science, University of Minnesota, St. Paul, MN 55108, USA; mschutz@umn.edu \\ * Correspondence: m.l.correaluna@massey.ac.nz
}

Received: 24 April 2020; Accepted: 12 June 2020; Published: 15 June 2020

Simple Summary: Improving the dietary crude protein utilisation in dairy cows is a key aspect of agronomically and environmentally sustainable production systems. The intensification process of grazing dairy systems identified with the increase of milking cows linked with the addition of supplementary feed along with the increasing use, and particularly inefficient use, of nitrogen fertiliser, has led to increasing pressure on the environment. However, feeding solely on pasture could result in an excess of crude protein intake relative to nutritional requirements, and this could reduce the dietary crude protein utilisation. In this study, we modelled the dietary crude protein utilisation, along with nitrogen excreta partitioning of milking cows, of two contrasting spring-calving pasture-based herds differing in intensification level in New Zealand. We found that feeding diets with higher fresh pasture proportions, such as those employed in low-intensification dairy systems, led to an excess of crude protein intake with greater nitrogen partitioned towards urine, which is sensitive in terms of body water eutrophication. In the high-intensity production system, the inclusion of low-crude protein supplements resulted in better dietary crude protein utilisation, along with less urinary nitrogen losses.

Abstract: In this study, we modelled and compared lactation curves of efficiency of crude protein utilisation (ECPU) and the nitrogen (N) excreta partitioning of milking cows of two contrasting spring-calving pasture-based herds to test some aspects of farming intensification practices on cow performance and $\mathrm{N}$ partition. In the low-intensity production system (LIPS), 257 cows were milked once-daily and fed diets comprised of pasture with low supplementary feed inclusion during lactation (304 kg pasture silage/cow). In the high-intensity production system (HIPS), 207 cows were milked twice-daily and fed pasture with higher supplementary feed inclusion (429 $\mathrm{kg}$ pasture silage and $1695 \mathrm{~kg}$ concentrate/cow). The dietary crude protein (CP) utilisation was calculated for each cow at every herd test date as the ECPU as a proportion of protein yield (PY) from the CP intake (CPI) derived from intake assessments based on metabolisable energy requirements, and the $\mathrm{CP}$ balance (CPB) calculated as the difference between CPI and PY. Total N excreta partitioned to faeces (FN) and urine (UN) was estimated by back-calculating $\mathrm{UN}$ from FN, considering dietary $\mathrm{N}$, and from $\mathrm{N}$ retained in body tissues, taking into account live weight change during the lactation. The higher CPI (2.7 vs. $2.5 \mathrm{~kg} \mathrm{CP} /$ day), along with the reduced milk yield (1100 kg milk/cow less), of the LIPS cows led to a lower ECPU ( $23 \%$ vs. $31 \%$ ) and to a higher СРB (2.1 vs. $1.8 \mathrm{~kg} \mathrm{CP} /$ day) when compared to the HIPS cows. Mean N excreta, and particularly UN, was significantly higher in LIPS cows, and this was explained by higher dietary $\mathrm{CP}$ and by the reduced PY when compared to the HIPS cows. 
Reducing the low-CP supplementation in the "de-intensified" herd lessened the ECPU, resulting in higher UN, which is sensitive in terms of body water eutrophication.

Keywords: dietary crude protein utilisation efficiency; dairy cows; grazing; excreta; intensification

\section{Introduction}

The efficiency with which lactating cows convert dietary crude protein $(\mathrm{CP})$ into milk protein can be measured by different criteria. For instance, it can be measured as the efficiency of $\mathrm{CP}$ utilisation (ECPU) calculated as the protein in milk (PY) in a day divided by the daily CP intake (CPI), or calculated considering an approximation of CP balance (CPB) estimated as CPI minus PY [1]. Compared to diets formulated from total mixed rations, diets comprised of predominantly fresh grazed temperate pastures are high in $\mathrm{CP}$ [nitrogen $(\mathrm{N})$ concentration $\times 6.25$ ] concentration in early spring and late autumn, containing mainly rumen-degradable protein at levels that regularly exceed animal requirements [2,3]. Therefore, lower efficiency of $\mathrm{N}$ utilisation, with values ranging from $13 \%$ to $33 \%$, would be expected in grazing conditions, and this would result in increases in excreted $N$, predominantly in urine [4], which elevates the nitrate-N levels in soil solution and groundwater $[5,6]$. Ledgard et al. [5] concluded that $\mathrm{N}$ leaching from grazed pastures increased exponentially with increased $\mathrm{N}$ inputs and that urinary-N contributed from $70 \%$ to $90 \%$ of total $\mathrm{N}$ leaching. Within grazing conditions, manipulating the dietary $\mathrm{CP}$ is limited, but when low $\mathrm{N}$ energy-dense concentrate is fed to pastured dairy cows, it was proven as a strategy to provide more energy for microbes to increase the microbial protein synthesis. A study conducted by Mulligan et al. [7] tested the effect of supplementing pastured dairy cows with low vs. high protein concentrate and demonstrated that low protein supplementation increased milk yield and reduced the CPI, and this was observed in improvements in the ECPU. By including low $\mathrm{CP}$ concentrates, minor changes in milk protein composition were documented [8], along with an increase of $\mathrm{N}$ excreted in faeces rather than urine [7,9].

The excess of dietary $\mathrm{CP}$ is rapidly converted to urea to avoid harm from the excess of ammonia. Urea is transported from the plasma and subsequently is transported to other fluids, such as saliva, in order to be recycled or to be excreted in urine, but it can also be found in milk as milk urea nitrogen (MUN). The relationship between MUN and dietary CP was reported to be positive in housed conditions [10-12] and in grazing conditions $[13,14]$. Hence, MUN has been proposed as a proxy to identify excess CP in diets [10]. Since milk is routinely collected and MUN is routinely determined in some countries by milk companies in order to follow animal and dietary characteristics, MUN is proposed as a convenient and non-invasive biomarker for dietary N-use efficiency $[10,15]$ and as a predictor of $\mathrm{N}$ excreted through urine into the environment [11,12].

In response to the global demand for dairy products, the New Zealand dairy industry has expanded rapidly since the 1990s [16], with dairy companies processing 7077 million litres of milk in 1990 and 20,702 million litres of milk in 2016 [17]. This expansion of the dairy industry was achieved through, among other factors, the genetic improvement of animals by implementing a well-defined national breeding program, by increasing the amount of bought-in supplementary feeds, and by increasing the use of $\mathrm{N}$ fertiliser, with a concomitant increase in the number of cows per ha [16]. Some aspects of this intensification process have reduced the farm $\mathrm{N}$ utilisation efficiency and increased the nutrient losses from these systems $[18,19]$. This has led to increasing pressure on soil and water resources, endangering native vegetation reserves and wetlands, and jeopardising the long-term sustainability of these intensified production systems [20,21]. As more inputs are included in these systems, production costs are likely to increase. In order to maintain profitability, cows would need to be milked at least twice-daily (TAD) to increase the number of secretory cells and promote their activity, which is linked with milk yield at peak lactation and with the persistency of lactation, respectively [22]. 
Despite the well-documented yield loss of systems with cows milked once-daily (OAD) [23-25], some farmers are adopting milking cows OAD throughout a full lactation as a production system for better lifestyle [26] and to reduce production costs [24]. An OAD production system is typically associated with lower intensification, especially lower use of supplementary feeds, and reduced labour [27]. Although previous research analysing OAD production systems focused on animal performance and economic outcomes [23-25], there is little information regarding the environmental implications of OAD production systems, especially in terms of ECPU and N losses at both cow and whole-farm levels. Since July 2013, Massey University Dairy 1 farm reduced the stocking rate from 2.7 to $2.1 \mathrm{cows} /$ ha and is managing a low-intensity production system, given the free-draining characteristic of its soils and the proximity to the Manawatu River and to Palmerston North city, to be in line with regional environmental guidelines to reduce nitrate leaching. Cows are milked OAD throughout the lactation with restricted supplementary feed as a strategy to reduce production costs. At the same time, Massey University Dairy 4 farm, which is located on a rural area and is comprised of silt loam soils of less nutrient leaching risk when compared to Dairy $1 \mathrm{farm}$, is managed as a high-intensity production system with cows milked TAD throughout the season and higher supplementation level included throughout the year. This represented an excellent opportunity to model and compare the dietary crude protein utilisation efficiency and $\mathrm{N}$ partitioning of cows of these two research herds throughout an entire lactation. It was hypothesised that the reduction in milk production along with a higher dietary CP in the "de-intensified" herd, as more pasture is fed in combination with less low-CP supplements offered, would decrease the ECPU and increase the $\mathrm{N}$ losses. Under these productive management conditions, cows are expected to have a positive energy balance and there might be a link with the CPB. Thus, the objective of this study was to model and compare two measures of dietary CP use efficiency, along with the $\mathrm{N}$ excreta partitioning of these two herds of contrasting spring-calving pasture-based production systems differing in intensification level, over an entire lactation in 2016. In addition, the relationship of MUN, along with dietary $\mathrm{CP}$ utilisation and with the partitioning of $\mathrm{N}$ to excreta, was explored.

\section{Materials and Methods}

\subsection{Description of Production Systems}

\subsubsection{Low-Intensity Production System}

The Massey University Dairy 1 farm is located on the outskirts of Palmerston North, which is in the lower North Island of New Zealand. This farm is managed as a low-intensity production system (LIPS), with 257 cows milked once-daily throughout the season, with a low stocking rate (2.1 cows/ha). The feed strategy includes fresh ryegrass (Lolium perenne)/white clover (Trifolium repens) pasture as the main diet component, with restricted supplementation and the sporadic use of grazing crops utilised in summer. The herd consisted of 66 Holstein-Friesian (F), 55 Jersey (J), and 136 Holstein-Friesian/Jersey crossbred cows $(\mathrm{F} \times \mathrm{J})$ with 12,15 , and 15 primiparous cows, respectively. Calving commenced on 11 July and continued up to 3 October 2016. Cows were milked daily at 06:30 throughout the season. After calving, milking cows had daily access as a single group to a new strip of pasture after each milking and were contained in their allocated forage area through the use of temporary electric fences. From December to March and in April, cows had daily access to a perennial herb-mix crop [mixture of plantain (Plantago lanceolata), chicory (Cichorium intybus), and red clover (Trifolium pratense)] at an allowance of $3.5 \mathrm{~kg}$ dry matter (DM) per cow per day. In March and May, alfalfa (Medicago sativa) was grazed at an allowance of $3 \mathrm{~kg}$ DM per cow per day. Turnips (Brassica campestris ssp. rapifera) were grazed at an allowance of $2.6 \mathrm{~kg}$ DM per cow per day only in February. Pasture silage was fed directly on the paddock in August and from March to May at a rate of $3.5 \mathrm{~kg}$ DM per cow per day. 


\subsubsection{High-Intensity Production System}

The Massey University Dairy 4 farm, located adjacent to the Dairy 1 farm, is a farm managed as a high-intensity production system (HIPS), with 207 cows milked twice-daily throughout the season, with a higher stocking rate ( $2.8 \mathrm{cows} / \mathrm{ha})$. Ryegrass-white clover pasture is also the main feed source but, in this case, higher supplementation level is included throughout the year. The herd was comprised of $51 \mathrm{~F}$ and $156 \mathrm{~F} \times \mathrm{J}$ cows, with 5 and 9 primiparous cows, respectively. Calving commenced on $1 \mathrm{July}$ and continued up to 26 September. Cows were milked daily at 05:30 and 14:30 throughout the season. After calving, milking cows had daily access as a herd to a new strip of pasture after each milking. During the lactation, maize (Zea mays) silage and grain-based concentrate were fed during the lactation at a rate of $3.5 \mathrm{~kg}$ DM per cow per day before the afternoon milking; $2 \mathrm{~kg}$ DM per cow per day was fed inside the parlour. Pasture silage was fed directly on the paddock in January at a rate of $3 \mathrm{~kg}$ DM per cow per day. In March, dried distillers grains were fed at a rate of $0.75 \mathrm{~kg}$ DM per cow per day during the morning milking; turnips were grazed in strips at an allowance of $2 \mathrm{~kg} D M$ per cow per day.

\subsection{Feed Allocation and Chemical Composition Measurements}

In the period of $24 \mathrm{~h}$ before each monthly herd test, pasture and crops allocated to each herd were sampled in order to quantify the ingredient proportions and to measure the chemical composition. Estimated pasture eaten [kg dry matter (DM) per cow per day] was calculated from pasture disappearance by measuring pregrazing DM minus postgrazing DM on the grazing area assigned per day divided by the total number of cows. The grazing area was measured using a global positioning system. Pre- and postgrazing pasture heights were measured with a rising-plate meter (Jenquip, New Zealand) following a "W" pattern across the grazing area on the basis of 3 sets of 50 readings on each occasion. Pasture mass was subsequently estimated using the following New Zealand national calibration equation for perennial ryegrass-white clover $(\mathrm{kg} \mathrm{DM} / \mathrm{ha}=140 \times$ compressed height + 500) [28]. Estimated crop (herb-mix, lucerne, turnips) consumption was calculated as crop cover pregrazing minus crop cover postgrazing, measured by harvesting three $0.1 \mathrm{~m}^{2}$ quadrats to ground level within the area allocated to each herd on a daily basis. Those measurements enabled the calculation of apparent pasture and crop utilisation and also the proportion of feed ingredients allocated to cows in each herd test.

Fresh pasture and crop samples (approximately $1500 \mathrm{~g}$ of wet weight) were harvested using the hand-plucking method [29] from about 50 sites on each walking transect to mimic herbage grazed by cows. Samples of maize and pasture silage were taken from the bunker, and grain-based concentrates and dried distillers grains were sampled directly from the feeders while cows were being milked. All samples were collected in a period of 24 hours prior to the milk sampling at 09:00 a.m. All samples were freeze-dried and ground (Wiley mill; Arthur H. Thomas, Philadelphia, PA) to pass through a 1.0-mm screen. The levels of ash, $\mathrm{CP}$, lipid, neutral detergent fibre (NDF), acid detergent fibre, organic matter digestibility, metabolisable energy (ME), and starch and soluble sugars were estimated by near-infrared reflectance spectrometry (NIRS) [30]. Calibrations for each component had been previously developed (Massey University Nutrition Laboratory, Palmerston North, New Zealand) using NIRS after scanning finely-ground pasture samples in the range of 400 to $2500 \mathrm{~nm}$. A Bruker MPA NIRS (Ettlingen, Germany) was used to scan the samples, and the resulting NIRS spectra were analysed using Optic user software version 5.0. (Ettlingen, Germany). The resulting NIRS calibration typically had a correlation of 0.90 when compared to the wet chemistry results for each component. Based on the proportions of each forage allowed and each individual feed ME content, the dietary ME content (megajoules of ME per $\mathrm{kg} \mathrm{DM}$ ) was calculated. Table 1 resumes the annual feed allocation (diet composition) of each production system with its chemical composition. 
Table 1. Mean feed allocation and chemical composition offered before each herd test in two contrasting pasture-based dairy production systems. Chemical composition expressed in metabolisable energy (ME, MJ ME/kg DM), and in percentages of crude protein (CP), acid detergent fibre (ADF), neutral detergent fibre (NDF), and organic matter digestibility (OMD).

\begin{tabular}{|c|c|c|c|c|c|c|c|c|c|c|c|c|c|}
\hline \multirow{3}{*}{ Item } & \multicolumn{13}{|c|}{ Production System } \\
\hline & \multicolumn{6}{|c|}{ Low Intensity } & \multicolumn{7}{|c|}{ High Intensity } \\
\hline & Pasture $^{1}$ & Pasture Silage & Brassica & Herb-Mix ${ }^{2}$ & Lucerne & Total & Pasture $^{1}$ & Pasture Silage & Brassica & Maize Silage & Concentrate $^{3}$ & DDG $^{4}$ & Total \\
\hline Feed allocation, \% DM & 92 & 3 & 1 & 3 & 1 & 100 & 60 & 8 & 1 & 15 & 15 & 1 & 100 \\
\hline ME, MJ ME/kg DM & 11.0 & 10.7 & 11.7 & 12.1 & 9.9 & 11.1 & 10.5 & 10.9 & 7.8 & 10.4 & 12.6 & 9.5 & 10.3 \\
\hline $\mathrm{CP}, \%$ of $\mathrm{DM}$ & 20 & 14 & 16 & 20 & 25 & 19 & 19 & 12 & 22 & 7 & 17 & 21 & 16 \\
\hline $\mathrm{ADF}, \%$ of $\mathrm{DM}$ & 22 & 34 & 22 & 15 & 21 & 22.8 & 24 & 40 & 18 & 28 & 2 & 11 & 21 \\
\hline $\mathrm{NDF}, \%$ of DM & 44 & 50 & 34 & 29 & 34 & 38.2 & 46 & 56 & 31 & 37 & 23 & 28 & 37 \\
\hline OMD, $\%$ of DM & 75 & 67 & 79 & 83 & 68 & 74.4 & 73 & 68 & 81 & - & - & - & 74 \\
\hline
\end{tabular}

${ }^{1}$ Perennial ryegrass (Lolium perenne)-white clover (Trifolium repens) pasture. ${ }^{2}$ Herb-mix crop comprised of plantain (Plantago lanceolata), chicory (Cichorium intybus), and red clover (Trifolium pratense). ${ }^{3}$ Grain-based concentrate. ${ }^{4}$ Dried distillers grains. 


\subsection{Animal Measurements}

Cows were identified using a radio frequency electronic identification system (Allflex New Zealand Ltd., Palmerston North, New Zealand), enabling daily body weight (BW) and daily BW change measurements to be generated using an automatic race walkover scale (WoW xR-3000, Tru-Test Ltd., Auckland, New Zealand). Milk yield (MY) was determined on each monthly herd test throughout the lactation by using mechanical milk meters (Tru-Test Field Collection meter WB HI/Pullout) provided by Livestock Improvement Corporation (Hamilton, New Zealand). Percentages of fat (FP) and protein (PP) were determined in each herd test using a FossomaticTM MilkoScan FT 120 instrument (Foss Electric, Hillerød, Denmark) on composite afternoon and morning aliquots for HIPS and from a unique sample for LIPS on each sampling date. Somatic cell count was determined using a FossomaticTM FC instrument (Foss Electric, Hillerød, Denmark) and converted to somatic cell score (SCS) as SCS = log2 (somatic cell count). Yields of fat (FY) and protein (PY) were calculated by using daily MY, along with FP and PP, respectively. In early (September), mid (December), and late (March) lactation stages, MUN (mg/dL) content and lactose percentage was determined using a CombiFoss ${ }^{\mathrm{TM}} 7$ instrument (Foss Electric, Hillerød, Denmark), following the CombiFoss technique [31] by MilkTestNZ (Hamilton, New Zealand). Each MUN record was converted into MUN yield (MUNY) (g MUN/cow/day) using daily MY. In synchrony with each herd test, BCS was assigned to each cow by a single research technician using a 10-point scale [32].

Macciotta et al. [33] identified that the mathematical properties of the Legendre polynomials functions were able to recognise a large number of curve shapes, enabling the modeling of the lactation curves of large groups of animals in contrasting productive conditions. In turn, lactation curves for milk production traits and BW were modelled from day 1 to day 275 of lactation, contemplating the maximum DIM of each cow using random regression models with Legendre polynomials of the third order, with the MIXED procedure of the Statistical Analysis System version 9.4 (SAS Institute Inc., Cary, NC, USA). Predicted values for each day were obtained from the polynomial function for each cow. The polynomial utilised is described in equation as

$$
\mathrm{Y}_{\mathrm{it}}=\alpha_{\mathrm{i} 0} \mathrm{P}_{\mathrm{i} 0}+\alpha_{\mathrm{i} 1} \mathrm{P}_{\mathrm{i} 1}+\alpha_{\mathrm{i} 2} \mathrm{P}_{\mathrm{i} 2}+\alpha_{\mathrm{i} 3} \mathrm{P}_{\mathrm{i} 3}
$$

where $Y_{i t}$ represents the level of production of a trait ${ }_{i}$ on day $t$ of the lactation after calving, with $\alpha$ being the regression coefficient to predict each trait mentioned above. The Legendre polynomials' functions of $P_{Y}$ were calculated as

$$
\begin{gathered}
P_{0}(t)=1, \\
P_{1}(t)=x, \\
P_{2}(t)=\frac{1}{2}\left(3 x^{2}-1\right), \text { and } \\
P_{3}(t)=\frac{1}{2}\left(5 x^{3}-3 x\right), \text { where } \\
x=-1+2 \frac{\left(t-t_{\min }\right)}{\left(t_{\text {max }}-t_{\min }\right)}
\end{gathered}
$$

according to Silvestre et al. [34].

Prediction of individual daily values of milk production traits along the lactation were accumulated in order to obtain the total lactation yield per cow for MY, milk solids yield (MSY; FY + PY), FY, PY, MUN, and MUNY.

\subsection{Energy Requirements and Intake Estimates}

Values of net energy requirements for maintenance, pregnancy, production, and daily BW variation were based on the French net energy system, where 1 unité fourragère lait is the net energy 
requirement for lactation equivalent to $1 \mathrm{~kg}$ of standard air-dried barley [35], equivalent to $7.11 \mathrm{MJ}$ of net energy or 11.85 MJ of ME. Net energy requirements were calculated using the following equation, with modifications by Berry et al. [36] for dairy cows in grazing conditions:

$$
\mathrm{NEreq}=\mathrm{NEm}+\mathrm{NEl}+\mathrm{NEg}+\mathrm{NEp}
$$

where NEreq is daily net energy requirement for each cow on each herd test date; NEm is daily net energy requirement for maintenance, including activity calculated as $(1.4+0.6 \times$ BW/100) $\times$ activity allowance factor of 1.2 for grazing conditions; $\mathrm{NEl}$ is the net energy for milk production calculated as $0.054 \times(\mathrm{FY} / 100)+0.031 \times(\mathrm{PY} / 100)+0.028 \times(\mathrm{LY} / 100)-0.015) \times \mathrm{MY} ; \mathrm{NEg}$ accounts for daily body weight variation, assuming an addition of 3.5 units when BW change is positive and -4.5 units when BW change is negative; NEp is daily net energy requirements for pregnancy where unité fourragère lait requirements for the $6 \mathrm{th}, 7 \mathrm{th}$, and 8 th month of pregnancy are $0.9,1.6$, and 2.6, respectively. Total net energy requirements were transformed to ME requirements by multiplying NEreq times $11.85 \mathrm{MJ}$ of ME. Then, apparent DMI (kg DM/cow per day) for all herd test occurrences was estimated by dividing total $\mathrm{ME}$ requirements by the dietary $\mathrm{ME}$ content in each instance.

\subsection{Definitions of Nitrogen Utilisation Efficiency and Nitrogen Excreta Estimates}

Two different assessments of $\mathrm{N}$ utilisation efficiency were used in this study. The ECPU was calculated as a proportion of CPI and from records of PY obtained from the monthly herd tests as

$$
\mathrm{ECPU}=\frac{\mathrm{PY}}{\mathrm{CPI}} \times 100
$$

with CPI determined by multiplying DMI by the CP concentration in the diet.

A complete $\mathrm{N}$ balance is required to examine the partition of total $\mathrm{N}$ intake towards $\mathrm{N}$ in faeces, urine, milk, and $\mathrm{N}$ retained in body tissues and the foetus [37], but these types of studies are expensive and cannot be undertaken on a large number of cows in grazing conditions. However, CPB can be calculated on a daily basis as the difference between CPI and PY [1], where the most inefficient cow has the highest CPB. It should be noted that the CPB cannot replace a full balance study, and this limits the interpretation of the results.

All the excess of dietary CP in the cow would be excreted except for a minor portion that would be retained by cows with positive energy balance. Each $\mathrm{kg}$ of BW change was assumed to contain $160 \mathrm{~g}$ of $\mathrm{CP}$ [38]. A back-calculation for $\mathrm{N}$ excreta estimation was undertaken, considering the retention of $\mathrm{N}$ in body tissues as constant. Total $\mathrm{N}$ excreta comprises $\mathrm{N}$ contained in faeces and urine during a given period. Compared to $\mathrm{N}$ excreted in urine (UN), $\mathrm{N}$ excreted in faeces (FN) is constant relative to DMI in lactating cows [39]. Faeces are the main fate of undigested feed $\mathrm{N}$, undigested microbial $\mathrm{N}$, and endogenous $\mathrm{N}$ [6]. Considering this, $\mathrm{FN}$ ( $\mathrm{g} \mathrm{N}$ excreted per day) was estimated, employing the formula of Reed et al. [40]:

$$
\mathrm{FN}=72.7-11.8 \times \mathrm{ME}-0.4 \times \mathrm{NDF}+3.5 \times \mathrm{CP}+0.2 \times \text { ForR }+9.3 \times \mathrm{DMI}-0.1 \times \mathrm{DIM}
$$

where ME is the metabolisable energy feed content, NDF is the neutral detergent fibre feed concentration, $\mathrm{CP}$ is the crude protein feed concentration, ForR is the proportion of pasture in the diet, DMI is the daily feed intake on dry-matter basis, and DIM is the days in milk. Subsequently, UN (g N urine excreted per day) was estimated as

$$
\mathrm{UN}=\text { feed } \mathrm{N}-\mathrm{FN}-\text { milk } \mathrm{N}-\mathrm{N} \text { retention }
$$

where UN is the $\mathrm{N}$ excreted in urine ( $\mathrm{g}$ of $\mathrm{N}$ per day), feed $\mathrm{N}$ represents the intake of $\mathrm{N}$ ( $\mathrm{g}$ of $\mathrm{CP}$ intake per day divided by 6.25), milk $\mathrm{N}$ (g of $\mathrm{N}$ in milk per day), and $\mathrm{N}$ retention corresponds to $\mathrm{N}$ retained in body tissues according to BW variation ( $\mathrm{g}$ retained per day). Similar to the two $\mathrm{N}$ 
use efficiencies analysed in this study (ECPU and CPB), the partition of N excreta was not predicted following the Legendre polynomials' functions but estimated according to cow performance and dietary characteristics in each case. Measurements of CPI, PY, and CP retained were converted into N by dividing each variable by 6.38 beforehand (as the average $\mathrm{N}$ content of protein is $160 \mathrm{~g}$ per $\mathrm{kg}$ of $\mathrm{BW}$ ) in order to account for the $\mathrm{N}$ partition fractions.

\subsection{Statistical Analyses}

The approach of this study is to examine how the two measures of dietary CP use efficiency and the $\mathrm{N}$ partition of pastured dairy cows is altered on different management practices (farm production system and supplementary feed inclusion) considering that these are representative situations of commercial farms with contrasting intensification levels in New Zealand conditions. The estimates of the third-order Legendre polynomial regression coefficients for each cow for each of the lactation measures of yields of milk, fat, protein, lactose, SCS, MUN, MUNY, BW, and BCS, along with lactation length, DMI, CPI, ECPU, and CPB, were analysed using the MIXED procedure of SAS (version 9.4; SAS Institute Inc., Cary, NC). The model included the fixed effects of the farm production system, lactation number, interactions between lactation number and farm production system, and as covariates, the deviation from median calving date, proportion of F, the heterosis effect among F and J, and the random effect of cows to account for repeated measures on the same cow. Estimates of Pearson correlation coefficients and standard errors for actual and predicted values of daily milk, fat and protein yield, somatic cell score, MUN, MUNY, BW, and BCS were obtained with the CORR procedure of SAS.

\section{Results}

Descriptive statistics of herd test records containing yields of milk, fat, lactose, and protein, along with SCS, MUN, and MUNY, are in Table 2. Mean MY of LIPS was $26 \%$ lower than HIPS, but that gap was reduced to $15 \%$ and $20 \%$, respectively, when comparing FY and PY between the two herds. There were higher mean, minimum, and maximum MUN concentrations in LIPS cows (Table 2 and Figure 2c), and standard deviations for MUN almost doubled in LIPS cows, reflecting larger variations between cows and during the lactation. Results for MUNY were similar among herds.

Table 2. Descriptive statistics of the lactation length records and herd test records of the yield of milk (MY), fat (FY), protein (PY) and lactose yields (LY), somatic cell scores (SCS), milk urea nitrogen (MUN), MUN yield, body weight, and body condition score (BCS) of grazing cows throughout a full lactation in two contrasting pasture-based dairy production systems.

\begin{tabular}{|c|c|c|c|c|c|c|c|c|c|c|}
\hline \multirow{3}{*}{ Variable } & \multicolumn{10}{|c|}{ Production System } \\
\hline & \multicolumn{5}{|c|}{ Low Intensity } & \multicolumn{5}{|c|}{ High Intensity } \\
\hline & $\mathbf{N}$ & Mean & SD & Min & $\operatorname{Max}$ & $\mathbf{N}$ & Mean & SD & Min & Max \\
\hline Lactation length, days & 257 & 269 & 33 & 127 & 319 & 207 & 272 & 36 & 110 & 321 \\
\hline Milk yield, kg/day & 2284 & 15.7 & 6.0 & 0.9 & 36.6 & 1217 & 21.2 & 5.5 & 3.0 & 37.7 \\
\hline Fat yield, kg/day & 2284 & 0.8 & 0.3 & 0.1 & 2.5 & 1217 & 1.0 & 0.2 & 0.2 & 1.5 \\
\hline Protein yield, kg/day & 2284 & 0.6 & 0.2 & 0.1 & 1.3 & 1217 & 0.8 & 0.2 & 0.2 & 1.4 \\
\hline Lactose yield, $\mathrm{kg} /$ day & 726 & 0.8 & 0.3 & 0.1 & 1.9 & 558 & 1.1 & 0.3 & 0.5 & 1.9 \\
\hline Somatic cell score ${ }^{1}$ & 2276 & 5.76 & 1.59 & 0.01 & 12.43 & 1217 & 5.13 & 1.45 & 1.58 & 12.02 \\
\hline $\mathrm{MUN}^{2}, \mathrm{mg} / \mathrm{dL}$ day & 726 & 13.11 & 4.70 & 4.25 & 28.83 & 557 & 9.72 & 2.58 & 2.84 & 18.42 \\
\hline MUNY 3 ,g/day & 726 & 1.9 & 0.8 & 0.3 & 4.7 & 557 & 2.1 & 0.6 & 0.4 & 3.9 \\
\hline Body weight, kg & 2359 & 487 & 70 & 320 & 684 & 1999 & 502 & 62 & 352 & 770 \\
\hline Body condition score & 2060 & 4.6 & 0.4 & 3.0 & 6.5 & 1405 & 4.2 & 0.4 & 3.0 & 5.5 \\
\hline
\end{tabular}

${ }^{1}$ The somatic cell count records were log2-transformed to SCS. ${ }^{2}$ Milk urea nitrogen. ${ }^{3}$ Milk urea nitrogen yield. Body condition score on a 1-10 scale.

Irrespective of the group of cows of this study, Pearson linear correlations between predicted and actual values for all traits examined were near unity (Table 3), which depicts the suitability of the 
Legendre orthogonal polynomials to model the cow performance during lactation. The accuracy of this methodology to model the lactation curves was superior for the milk production traits, with correlations greater than 0.923 when compared to other cow performance parameters such as BW or BCS, with values of 0.988 and 0.868 , respectively. Correlations of actual MUN and MUNY with their corresponding predictive values were equal to 0.991 and 0.960 in LIPS, and to 0.968 and 0.898 in HIPS, respectively.

Table 3. Estimates of Pearson correlation coefficients and standard error for actual and predicted 1 values of daily milk production traits, body weight, and body condition score in two contrasting pasture-based dairy production systems: a low-intensity production system (LIPS) and a high-intensity production system (HIPS).

\begin{tabular}{cccc}
\hline Trait & \multirow{2}{*}{ Overall } & \multicolumn{2}{c}{ Production System } \\
\cline { 3 - 4 } & & LIPS & HIPS \\
\hline Milk yield, kg/day & $0.997 \pm 0.003$ & $0.996 \pm 0.004$ & $0.995 \pm 0.005$ \\
Fat yield, kg/day & $0.992 \pm 0.004$ & $0.992 \pm 0.006$ & $0.990 \pm 0.007$ \\
Protein yield, kg/day & $0.994 \pm 0.004$ & $0.995 \pm 0.005$ & $0.991 \pm 0.007$ \\
Somatic cell score ${ }^{2}$ & $0.923 \pm 0.005$ & $0.922 \pm 0.006$ & $0.916 \pm 0.008$ \\
Milk urea nitrogen, mg/dL day & $0.989 \pm 0.003$ & $0.991 \pm 0.004$ & $0.968 \pm 0.008$ \\
Milk urea nitrogen yield, g/day & $0.941 \pm 0.007$ & $0.960 \pm 0.007$ & $0.898 \pm 0.014$ \\
Body weight, kg $_{\text {Body condition score }}{ }^{3}$ & $0.988 \pm 0.002$ & $0.995 \pm 0.001$ & $0.976 \pm 0.003$ \\
Body & $0.868 \pm 0.006$ & $0.846 \pm 0.009$ & $0.804 \pm 0.012$ \\
\hline
\end{tabular}

${ }^{1}$ The predicted values were modelled with a third-order Legendre polynomial. ${ }^{2}$ The somatic cell count records were $\log 2$-transformed to somatic cell score. ${ }^{3}$ Body condition score on a 1-10 scale.

Table 4 has the least squares means of the regression coefficient estimates employed to obtain predicted values for the MY traits and cow performance throughout the lactation. Differences in alphas $(p<0.001)$ are consistent with milk production performance depicted in the descriptive statistics shown in Table 2, with higher $\alpha_{0}$ (intercept) in all traits of milk production and lower $\alpha_{0}$ for SCS in HIPS. A similar trend was observed and confirmed with the descriptive statistics with regards to BW and BCS in both herds. Likewise, $\alpha_{0}$ of MUN was higher in the LIPS cows, corroborating results previously described.

There was a significant effect of production system management on total milk production in the present study, with considerably higher MY in HIPS (Figure 1 and Table 5). After adjusting cow performance for heterosis effects between $\mathrm{F}$ and $\mathrm{J}$, proportion of $\mathrm{F}$, lactation number, and deviation of median calving date. LIPS cows had 13\% lower MSY during the lactation, and this was associated with lower DMI $(p<0.001)$. In the LIPS herd, the higher CPI $(<0.001)$, along with a significant lower PY, resulted in an inferior ECPU (Figure 2a). Compared to the HIPS herd, values for CPB were significantly higher in LIPS (Table 5 and Figure 2b), demonstrating an excess of $\mathrm{CP}$ for this group of cows. Values for MUN were significantly lower in HIPS, but MUNY was not different between LIPS and HIPS cows ( $p$ $=0.058)$ (Table 5 and Figure $2 c, d)$. 
Table 4. Least squares means and standard errors of the estimates of regression coefficients of the lactation curves for milk, fat, protein and lactose yields, somatic cell score, milk urea nitrogen (MUN) and MUN yield, body weight and body condition score modelled with a third-order Legendre polynomial fitted to grazing cows throughout a full lactation in two contrasting pasture-based dairy production systems: a low-intensity production system (LIPS) and a high-intensity production system (HIPS).

\begin{tabular}{cccccc}
\hline Trait & Herd & $\alpha_{0}$ & $\alpha_{1}$ & $\alpha_{2}$ & $\alpha_{3}$ \\
\hline Milk yield, kg/day & LIPS & $15.20^{\mathrm{b}} \pm 0.16$ & $-6.94^{\mathrm{b}} \pm 0.12$ & $-1.13^{\mathrm{b}} \pm 0.06$ & $0.21^{\mathrm{b}} \pm 0.02$ \\
& HIPS & $19.33^{\mathrm{a}} \pm 0.22$ & $-5.83^{\mathrm{a}} \pm 0.17$ & $-1.90^{\mathrm{a}} \pm 0.09$ & $0.10^{\mathrm{a}} \pm 0.02$ \\
Fat yield, kg/day & LIPS & $0.78^{\mathrm{b}} \pm 0.01$ & $-0.29^{\mathrm{b}} \pm 0.01$ & $-0.03^{\mathrm{b}} \pm 0.00$ & $-0.04^{\mathrm{b}} \pm 0.00$ \\
& HIPS & $0.89^{\mathrm{a}} \pm 0.01$ & $-0.13^{\mathrm{a}} \pm 0.01$ & $-0.02^{\mathrm{a}} \pm 0.00$ & $-0.03^{\mathrm{a}} \pm 0.00$ \\
Protein yield, kg/day & LIPS & $0.62^{\mathrm{b}} \pm 0.01$ & $-0.21^{\mathrm{b}} \pm 0.01$ & $-0.04 \pm 0.00$ & $-0.01^{\mathrm{b}} \pm 0.00$ \\
& HIPS & $0.73^{\mathrm{a}} \pm 0.01$ & $-0.08^{\mathrm{a}} \pm 0.01$ & $-0.05 \pm 0.00$ & $0.02^{\mathrm{a}} \pm 0.00$ \\
Lactose yield, kg/day & LIPS & $0.77^{\mathrm{b}} \pm 0.01$ & $-0.37 \pm 0.01$ & $0.01^{\mathrm{b}} \pm 0.00$ & $0.05^{\mathrm{a}} \pm 0.00$ \\
& HIPS & $1.07^{\mathrm{a}} \pm 0.01$ & $-0.39 \pm 0.01$ & $0.02^{\mathrm{a}} \pm 0.00$ & $-0.05^{\mathrm{b}} \pm 0.00$ \\
Somatic cell score ${ }^{1}$ & LIPS & $5.80^{\mathrm{a}} \pm 0.07$ & $1.12^{\mathrm{a}} \pm 0.05$ & $0.04^{\mathrm{b}} \pm 0.04$ & $0.08 \pm 0.02$ \\
& HIPS & $5.02^{\mathrm{b}} \pm 0.10$ & $0.71^{\mathrm{b}} \pm 0.07$ & $0.66^{\mathrm{a}} \pm 0.05$ & $0.03 \pm 0.03$ \\
Milk urea, mg/dL day & LIPS & $14.49^{\mathrm{a}} \pm 0.14$ & $7.64^{\mathrm{a}} \pm 0.14$ & $6.00^{\mathrm{a}} \pm 0.15$ & $-0.59 \pm 0.05$ \\
& HIPS & $10.94^{\mathrm{b}} \pm 0.20$ & $3.91^{\mathrm{b}} \pm 0.19$ & $3.26^{\mathrm{b}} \pm 0.21$ & $-0.49 \pm 0.08$ \\
Milk urea yield, g/day & LIPS & $1.99^{\mathrm{b}} \pm 0.03$ & $-0.17 \pm 0.02$ & $0.48^{\mathrm{b}} \pm 0.01$ & $-0.33 \pm 0.01$ \\
& HIPS & $2.10^{\mathrm{a}} \pm 0.04$ & $-0.14 \pm 0.03$ & $0.50^{\mathrm{a}} \pm 0.01$ & $-0.33 \pm 0.02$ \\
Live weight, kg & LIPS & $488.06^{\mathrm{a}} \pm 2.71$ & $18.35^{\mathrm{b}} \pm 0.94$ & $13.48^{\mathrm{b}} \pm 0.71$ & $-6.15^{\mathrm{a}} \pm 0.91$ \\
& HIPS & $477.34^{\mathrm{b}} \pm 3.72$ & $23.81^{\mathrm{a}} \pm 1.29$ & $20.61^{\mathrm{a}} \pm 0.98$ & $-13.66^{\mathrm{b}} \pm 1.25$ \\
Body condition score ${ }^{2}$ & LIPS & $4.59^{\mathrm{a}} \pm 0.02$ & $-0.13 \pm 0.01$ & $0.23^{\mathrm{b}} \pm 0.01$ & $0.05^{\mathrm{a}} \pm 0.00$ \\
& HIPS & $4.25^{\mathrm{b}} \pm 0.02$ & $-0.12 \pm 0.01$ & $0.27^{\mathrm{a}} \pm 0.01$ & $-0.01^{\mathrm{b}} \pm 0.01$ \\
\hline
\end{tabular}

$\mathrm{ab}$ Means with different superscripts within trait indicates they were significantly different $(p<0.05) .{ }^{1}$ The somatic cell count records were log2-transformed to somatic cell score. ${ }^{2}$ Body condition score on a 1-10 scale.

Table 5. Least squares means ( \pm standard errors) of lactation length, total yield of milk, milk solids, fat, protein and lactose, SCS, body weight and body condition score, dry matter intake (DMI), crude protein (CP) intake (CPI), milk urea nitrogen (MUN) and MUN yield (MUY), efficiency of CP utilisation (ECPU), and $\mathrm{CP}$ balance $(\mathrm{CPB})$ of grazing cows throughout a full lactation in two contrasting pasture-based dairy production systems.

\begin{tabular}{cccc}
\hline \multirow{2}{*}{ Item (per Cow) } & \multicolumn{2}{c}{ Production System } & \\
\cline { 2 - 4 } & Low Intensity & High Intensity & $p$ - Value $\mathbf{1}^{\mathbf{2}}$ \\
\cline { 2 - 4 } $\mathrm{N}$ & 257 & 207 & \\
Lactation length, days & $272 \pm 2$ & $271 \pm 3$ & 0.719 \\
Total milk yield, kg & $4232.40 \pm 55.3$ & $5332.10 \pm 75.9$ & $<0.001$ \\
Total milk solids yield, kg & $387.6 \pm 4.4$ & $443.7 \pm 6.1$ & $<0.001$ \\
Total fat yield, kg & $217.4 \pm 2.5$ & $243.9 \pm 3.5$ & $<0.001$ \\
Total protein yield, kg & $170.5 \pm 2$ & $199.7 \pm 2.8$ & $<0.001$ \\
Total lactose yield, kg & $214.7 \pm 3$ & $296.3 \pm 4.1$ & $<0.001$ \\
Somatic cell score 2 & $5.73 \pm 0.07$ & $4.95 \pm 0.1$ & $<0.001$ \\
Body weight, kg & $487 \pm 3$ & $475 \pm 4$ & 0.012 \\
Body condition score 3 & $4.6 \pm 0.02$ & $4.26 \pm 0.02$ & $<0.001$ \\
DMI, kg/day & $16.21 \pm 0.07$ & $18.49 \pm 0.13$ & $<0.001$ \\
CPI, kg/day & $3.13 \pm 0.01$ & $2.8 \pm 0.03$ & $<0.001$ \\
MUN, mg/dL & $13.20 \pm 0.34$ & $9.99 \pm 0.23$ & $<0.001$ \\
MUNY, g & $535.06 \pm 19.6$ & $565.01 \pm 12.57$ & 0.058 \\
ECPU, \% & $20.13 \pm 0.13$ & $27.65 \pm 0.33$ & $<0.001$ \\
CPB, kg CP/day & $2.51 \pm 0.01$ & $2.03 \pm 0.03$ & $<0.001$ \\
\hline
\end{tabular}

${ }^{1}$ Differences between treatments were considered significant at $p<0.05 .{ }^{2}$ The somatic cell count records were $\log 2$-transformed to somatic cell score. ${ }^{3}$ Body condition score on a 1-10 scale. 

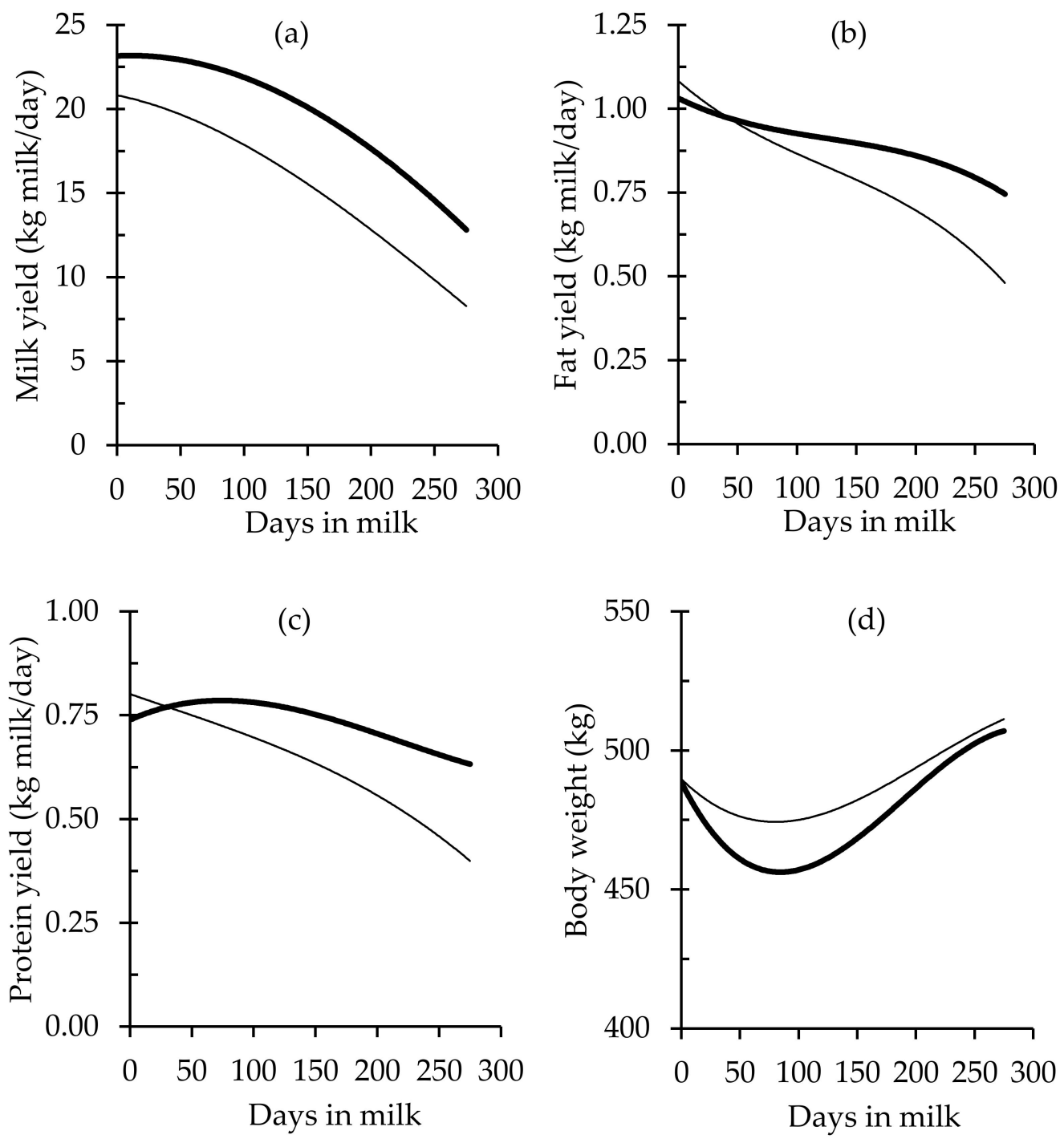

Figure 1. Predicted lactation curves of yields of (a) milk, (b) fat, and (c) protein, and (d) body weight of grazing cows throughout a full lactation in two contrasting pasture-based dairy production systems: a low-intensity production system (-) and a high-intensity production system (一).

Estimates of mean $\mathrm{N}$ excreta during the lactation ( $\mathrm{g} \mathrm{N}$ per day) was higher in the LIPS cows when compared to the HIPS cows ( $p<0.001$; Figure 3$)$, with a higher proportion of UN $(p<0.001$; Figure 3b). Mean FN per day was higher in HIPS ( $p=0.0018$; Figure 3c). Cows in HIPS had significantly higher $\mathrm{DMI}$, with a higher proportion of nonpasture supplements of lower $\mathrm{CP}$ (compared to fresh grazed pasture) included throughout the lactation, which led to a diet lower in CP (Figure 3d). 

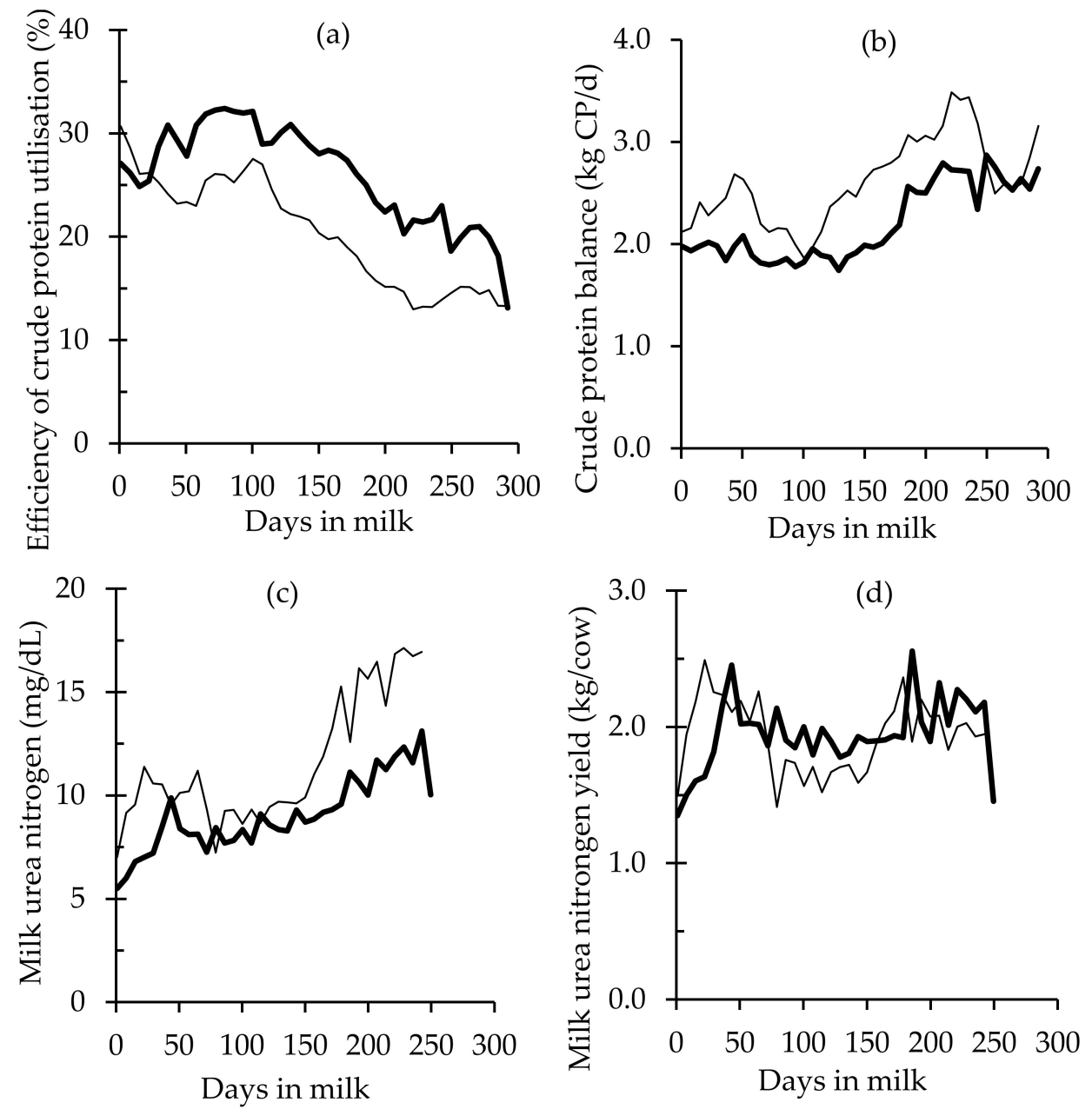

Figure 2. Predicted lactation curves of nitrogen use efficiency calculated as (a) the efficiency of crude protein (CP) utilisation, (b) the CP balance, (c) milk urea nitrogen (MUN; mg/dL), and (d) MUN yield (g) of grazing cows throughout a full lactation in two contrasting pasture-based dairy production systems: a low-intensity production system (-) and a high-intensity production system (-).
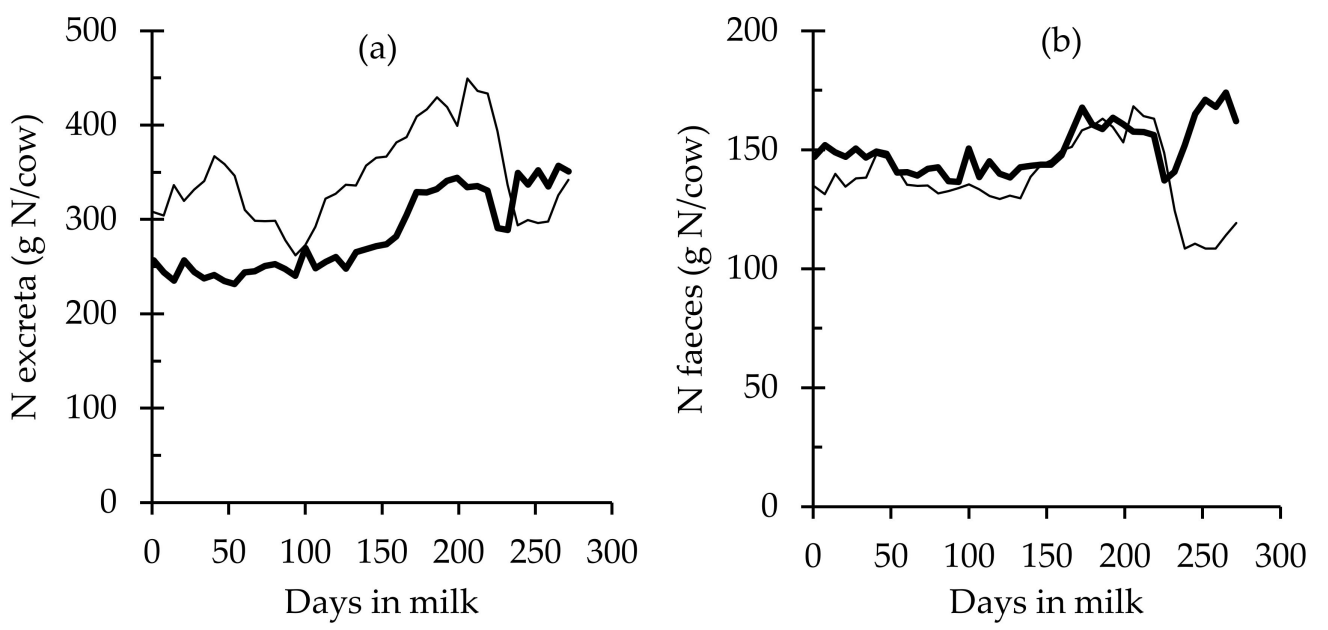

Figure 3. Cont. 

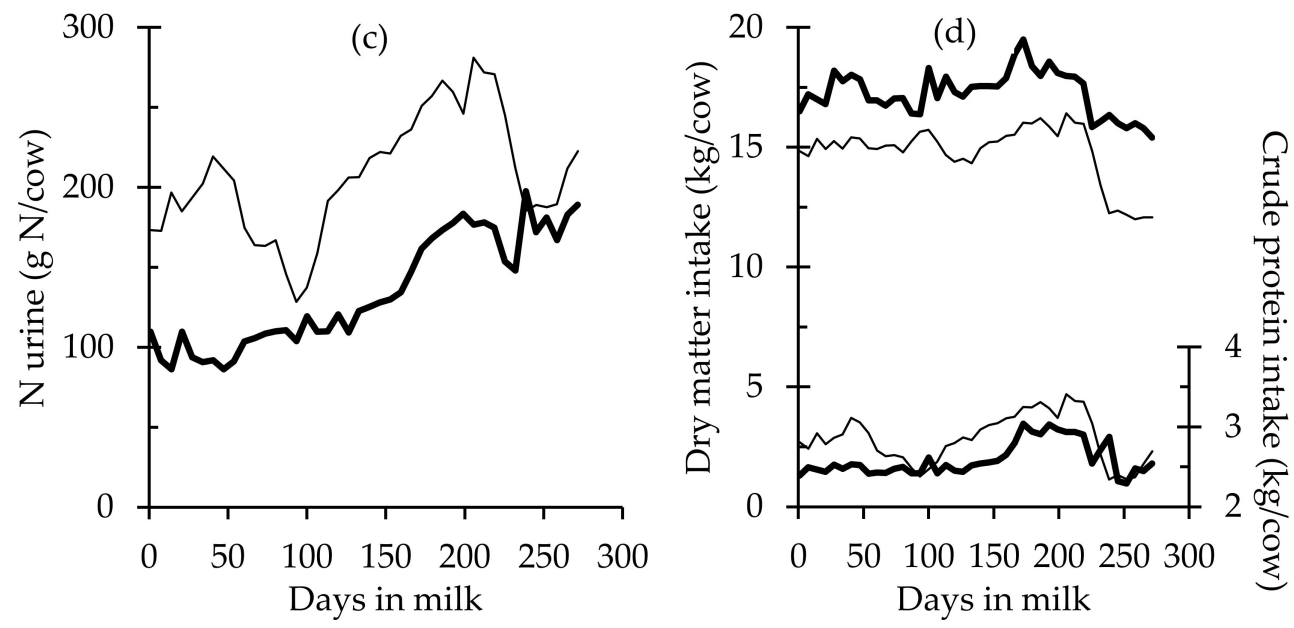

Figure 3. Estimations of (a) total nitrogen (N) excreta per cow (g N/day) and partitioned into (b) urine ( $\mathrm{g} \mathrm{N}$ urine/day) and (c) faeces ( $\mathrm{g} \mathrm{N}$ faeces/day), along with (d) dry matter intake (DMI) per cow ( $\mathrm{kg} \mathrm{DMI} /$ day) and crude protein intake (CPI) per cow (kg CPI/day), in two grazing dairy systems: a low-intensity production system (-) and a high-intensity production system (-).

\section{Discussion}

In the present study, two measures of dietary $\mathrm{CP}$ use efficiency, along with estimations of $\mathrm{N}$ excreta partitioning, in two contrasting dairy production systems of dissimilar intensification levels are described. Although it was impractical to allocate two levels of supplementary feed inclusion in each herd milked once or twice daily, no research describing the performance of dietary $\mathrm{CP}$ use efficiency during the lactation of pastured cows with varying milking frequency has been found in previous literature. There was a substantial difference in the intercept between regressions of ECPU of LIPS and HIPS herds (Figure 2a) due to differences in milk production and in CPI (Figure 3d). Diets high in CP involve an extra nutritional "cost" to eliminate the surplus $\mathrm{N}$ from the animal. A review of $\mathrm{N}$ metabolism from a large compiling of studies indicated that $250 \mathrm{~g}$ additional ammonia absorption per day as a result of feeding CP above requirements would require an extra 7 MJ per day [41], reducing energy destined for milk production and reducing ECPU. The better BCS of the LIPS cows demonstrated that the higher CPI did not affect the energy balance, and this was due to the lower MY observed in this group of cows. A higher CPB was observed throughout the lactation in the LIPS cows compared to HIPS cows, reflecting more $\mathrm{N}$ than could be allocated towards PY (by limiting MY), resulting in an increase in $\mathrm{N}$ concentration in excreta. Determination of $\mathrm{N}$ losses in skin, scurf, hair, and excreta in the lactating cow is difficult and can lead to sources of errors when studying the kinetics of N [37]. Nevertheless, the substantial gap in ECPU (and CPB) between LIPS and HIPS is undeniable and overcomes such potential measurement errors (Figure 2a,b).

Contrary to the intercepts for ECPU regressions, the intercepts for $\mathrm{CPB}$ tended to be similar for both herds (Figure 2b). This is due to a counterbalance between the differences in CPI and PY of both herds in early lactation. The negative slope in CPB of both LIPS and HIPS herds demonstrated that the body tissue mobilisation in early lactation contributed not only with energy but also with protein towards the intense metabolic demand that a transition cow (from dry period to peak lactation) faces in its first days of lactation [42]. By feeding diets with higher supplementation and milking cows twice-daily, HIPS cows produced more milk, and this signified that more CP was partitioned towards PY and this was seen in less CPB when compared to LIPS cows. Attention should be paid to management practices that reduce milk production because all the $\mathrm{CP}$ not allocated in milk would escape in excreta.

The liver, along with the portal-drained viscera, are tissues of high internal N metabolic activity, and while they represent less than $10 \%$ of $\mathrm{BW}$, they are responsible for the major $\mathrm{N}$ metabolic exchange 
in ruminants [41], including ureagenesis, a vital mechanism to overcome poisoning from the excess of ammonia present in the systemic circulation. That labile $\mathrm{N}$ pool is highly influenced by feeding management [43], among other factors. In turn, urea is transported from the plasma to other fluids such as saliva in order to be recycled and is excreted mainly in urine, but it is also present in milk. The relationship between urine urea $\mathrm{N}$ and MUN was recognised by a number of authors [11,12]. In contrast to the higher MUN in the LIPS herd when compared to the HIPS herd in the present study, earlier studies of Friggens and Rasmussen [44] and Nielsen et al. [45] reported increases in MUN with decreases in milking intervals, but the explanations were speculative, with authors suggesting that there might be an interaction with time of feed intake and time of milk sampling that results in disturbances in MUN determinations. Irrespective of management practices in each herd, the results of the present study confirmed a positive relationship between MUN and CPI [46,47]. Compared to the HIPS herd, CPI of the LIPS herd was always higher and was accompanied by higher MUN throughout the lactation (Figure 2c), with the exception of the period around day 90 of lactation when values of CPI of the HIPS herd were similar to the LIPS herd, resulting in similar MUN. Cows milked in the LIPS herd were fed mainly ryegrass pastures of high quality and high CP concentration, with minor inclusion of supplements in the diet. This represents an imbalance of energy: the protein ratio [2] leading to increases in N excreta and MUN. On the contrary, De Campeneere et al. [48] reported higher urine $\mathrm{N}$ levels along with lower plasma urea $\mathrm{N}$ and MUN for cows fed pasture silage compared to cows fed maize silage diets and attributed this to the high consumption of potassium and sodium from pasture silage diets. However, there might be a confounding factor, considering the differences in DMI between the pastured-dairy cows in this present study and the cows in housed production systems utilised by De Campeneere et al. [48]. The ensiling process can considerably alter the nutritive value of forage, leading to increases in nonprotein $\mathrm{N}$ at the expense of true protein, the rate of proteolysis, and concentrations of volatile fatty acids, as well as reductions in carbohydrate content [49]. While finding substantial differences in ECPU between these two herds, MUNY was similar for both herds (Table 5). This equity was in response to higher MY, along with lower MUN in the HIPS herd and the opposite in the LIPS herd. Because of this compensation between MUN and MY, an erratic relationship of MUN with both ECPU and CPB is reported in this study. At day 90 of lactation, cows had the same MUN and equal CPI, but the ECPU was higher and CPB was lower in the HIPS cows. Similarly, Barros et al. [46] reported some inconsistencies in the relationship of ECPU and MUN, with a positive relationship between MUN and feed efficiency of 0.71 , leading to higher MY and PY. On the contrary, Nousiainen et al. [12] improved the estimates of UN excretion and ECPU with back-calculations by including MUNY. However, Nousiainen et al. [12] used housed cows fed total mixed rations with lower dietary CP compared to the grazing conditions of the present study. Several authors and results from the present study suggest that the relationship between MUN and ECPU is governed by several factors, including MY, BW, lactation stage, between-animal variation, and nutritional management [38,43].

This study indicated that irrespective of the lower DMI of the LIPS cows, CPI was increased through ingestion of a larger proportion of fresh pasture with higher digestible N. Compared to the HIPS cows, the greater CPI along with lower PY of the LIPS cows (Table 5 and Figure 3d) resulted in a lower ECPU and a greater CPB with inevitable increases in N excreta. Moreover, in the period around day 90 of lactation, similar CPI for cows of both herds resulted in higher UN in LIPS cows, and this was confirmed by the disparity in the ECPU and in the CPB analysed in this study at this particular time. A number of authors also reported the same strong negative relationship between CP in the diet and the CP use efficiency, and with the increase in N excreta of lactating cows $[9,46,47]$.

Results from the present study confirmed on a daily basis that feeding concentrates to supplement grass-based diets could shift $\mathrm{N}$ excretion from urine to faeces [7,9]. While LIPS cows had mean daily calculated UN values of $199 \mathrm{~g}$ N per day compared to $134 \mathrm{~g}$ N per day in HIPS cows, HIPS cows had $139 \mathrm{~g} \mathrm{~N}$ per day in FN compared to $134 \mathrm{~g} \mathrm{~N}$ per day in LIPS cows. Proportionally, cows belonging to HIPS partitioned more $\mathrm{N}$ towards faeces, in which $\mathrm{N}$ is less volatile than $\mathrm{N}$ in urine, which may be 
converted to ammonia and nitrous oxide at a slower rate [5,19]. This aspect of the alteration in $\mathrm{N}$ excreta partition towards faeces could be interesting from an environmental perspective, considering that reducing the rate of $\mathrm{N}$ loss may result in less $\mathrm{N}$ leached from the system [5].

In the first 100 days of lactation, HIPS cows had greater mobilisation of body tissue (Figure 1d), which contributed to the $\mathrm{CP}$ requirements of those cows (considering that $1 \mathrm{~kg}$ of BW mobilisation equates to $160 \mathrm{~g}$ of $\mathrm{CP}$; [38]) facing a high demand for nutrients for milk production and other metabolic processes, including the uterine involution postpartum. If not for this mobilisation of BW, it would have been difficult for HIPS cows to achieve the recorded high MY (mean peak milk production of $25 \mathrm{~kg}$ ) with a diet comprising $14.5 \%$ CP in early and mid-lactation, reducing the ECPU by achieving lower PY. Trevaskis and Fulkerson [50] suggested that the lower level of MUN aligned with peak milk yield was attributed to nutrient mobilisation in early lactation, as more $\mathrm{N}$ available would be potentially allocated to milk protein synthesis, affecting the ECPU and the CPB, as it was observed in this study. A recent study by Daniel et al. [42] recommended subdividing the lactation into stages when analysing protein and energy requirements of lactation.

Additional mitigation techniques must be studied in order to alleviate the $\mathrm{N}$ loss to the environment of grass-based systems, specifically in low-intensity OAD systems. For example, the present study indicates that feeding low $\mathrm{CP}$ concentrates to dairy cows grazing good-quality pasture would reduce their CPI, with no negative effect on feed intake or milk production, and at the same time, some shifting of $\mathrm{N}$ excreta from urine towards faeces can be achieved. Moreover, the implementation of strategic supplementation in low intensity grazing systems should need to be carefully designed by detecting true deficits and surplus of nutrients (primarily energy and protein) as a promising way for dairy farmers to be more competitive, while reducing the environmental footprint $[15,18,19]$.

\section{Conclusions}

Both measures of CP use efficiency in LIPS and in HIPS were driven by the CPI and by the levels of milk production. The combined effect of extra supplementary feed and milking frequency employed, considering each intensification approach in each production system, affected the overall milk production performance, and, consequently, the ECPU was higher in HIPS cows. Moreover, the ECPU of LIPS cows was reduced by feeding diets comprising mainly fresh pasture high in CP. The LIPS cows had a higher $\mathrm{CPB}$ as a result of lower milk protein synthesis and higher dietary $\mathrm{CP}$ when compared to HIPS cows.

Lactation curves of MUN for LIPS and HIPS cows were in line with levels of CP fed, but no association was found with $\mathrm{CP}$ use efficiency using the approaches proposed in the present study. The compensation observed between MY and MUN levels in both herds resulted in similar MUNY, and this explained the similarities in MUN levels at some stages of the lactation. Thus, an erratic relationship of MUN with both ECPU and CPB was observed in this study.

Due to an excess of dietary CP in LIPS cows, UN was elevated, and as this is the most sensitive fraction of excreta. Mitigating strategies must be studied and evaluated in regards to alleviating $\mathrm{N}$ loss to the environment in lower-input dairy production systems. It is noteworthy to highlight that this paper demonstrated that some management practices considered as part of the deintensification of pasture-based dairy production systems, such as the reduction of supplementary feed, are worthy of consideration since a detrimental effect on the efficiency of $\mathrm{CP}$ utilisation with more $\mathrm{N}$ partitioned towards urine was observed.

Author Contributions: Conceptualization: all authors; methodology: M.C.-L. and N.L.-V.; validation: M.C.-L. and N.L.-V.; formal analysis: M.C.-L. and N.L.-V.; investigation: M.C.-L.; resources: D.D., P.K., and N.L.V.; data curation: M.C.-L. and N.L.-V.; writing-original draft preparation: M.C.-L.; writing-review and editing: all authors; supervision: N.L.V.; project administration: N.L.-V.; funding acquisition: D.D., P.K., and N.L.-V. All authors have read and agreed to the published version of the manuscript.

Acknowledgments: The principal author acknowledges the assistance from Colin Holmes Dairy Scholarship, George Mason Sustainable Land Use Scholarship, and the Cecil Elliot Trust of New Zealand. 
Conflicts of Interest: The authors declare no conflict of interest.

\section{References}

1. Zamani, P. Chapter 7: Efficiency of Lactation. In Milk Production-An Up-to-Date Overview of Animal Nutrition, Management and Health; Chaiyabutr, N., Ed.; Intech: Rijeka, Croatia, 2012; pp. 139-150.

2. Kolver, E.S.; Muller, L.D. Performance and nutrient intake of high producing Holstein cows consuming pasture or a total mixed ration. J. Dairy Sci. 1998, 81, 1403-1411. [CrossRef]

3. Waghorn, G.C.; Clark, D.A. Feeding value of pastures for ruminants. N. Z. Vet. J. 2004, 52, 320-331. [CrossRef] [PubMed]

4. Kebreab, E.; France, J.; Beever, D.E.; Castillo, A.R. Nitrogen pollution by dairy cows and its mitigation by dietary manipulation. Nutr. Cycl. Agroecosyst. 2001, 60, 275-285. [CrossRef]

5. Ledgard, S.F.; Schils, R.; Eriksen, J.; Luo, J. Environmental impacts of grazed clover-grass pastures. Irish J. Agricult. Food Res. 2009, 48, 209-226.

6. Tamminga, S. Nutrition management of dairy cows as a contribution to pollution control. J. Dairy Sci. 1992, 75, 345-357. [CrossRef]

7. Mulligan, F.J.; Dillon, P.; Callan, J.J.; Rath, M.; O’Mara, F.P. Supplementary concentrate type affects nitrogen excretion of grazing dairy cows. J. Dairy Sci. 2004, 87, 3451-3460. [CrossRef]

8. Mackle, T.R.; Bryant, A.M.; Petch, S.F.; Hooper, R.J.; Auldist, M.J. Variation in the composition of milk protein from pasture-fed dairy cows in late lactation and the effect of grain and silage supplementation. N. Z. J. Agric. Res. 1999, 42, 147-154. [CrossRef]

9. Hristov, A.N.; Ropp, J.K.; Grandeen, K.L.; Abedi, S.; Etter, R.P.; Melgar, A.; Foley, A.E. Effect of carbohydrate source on ammonia utilization in lactating dairy cows. J. Animal Sci. 2005, 83, 408-421. [CrossRef]

10. Broderick, G.A.; Clayton, M.K. A statistical evaluation of animal and nutritional factors influencing concentrations of milk urea nitrogen. J. Dairy Sci. 1997, 80, 2964-2971. [CrossRef]

11. Jonker, J.S.; Kohn, R.A.; Erdman, R.A. Using milk urea nitrogen to predict nitrogen excretion and utilization efficiency in lactating dairy cows. J. Dairy Sci. 1998, 81, 2681-2692. [CrossRef]

12. Nousiainen, J.; Shingfield, K.J.; Huhtanen, P. Evaluation of milk urea nitrogen as a diagnostic of protein feeding. J. Dairy Sci. 2004, 87, 386-398. [CrossRef]

13. Bargo, F.; Muller, L.D.; Delahoy, J.E.; Cassidy, T.W. Milk response to concentrate supplementation of high producing dairy cows grazing at two pasture allowances. J. Dairy Sci. 2002, 85, 1777-1792. [CrossRef]

14. Totty, V.K.; Greenwood, S.L.; Bryant, R.H.; Edwards, G.R. Nitrogen partitioning and milk production of dairy cows grazing simple and diverse pastures. J. Dairy Sci. 2013, 96, 141-149. [CrossRef] [PubMed]

15. Gourley, C.J.P.; Aarons, S.R.; Powell, J.M. Nitrogen use efficiency and manure management practices in contrasting dairy production systems. Agric. Ecosyst. Environ. 2012, 147, 73-81. [CrossRef]

16. Macdonald, K.A.; Penno, J.W.; Lancaster, J.A.S.; Bryant, A.M.; Kidd, J.M.; Roche, J.R. Production and economic responses to intensification of pasture-based dairy production systems. J. Dairy Sci. 2017, 100, 6602-6619. [CrossRef]

17. LIC. New Zealand Dairy Statistics 2016-17; DairyNZ: Hamilton, New Zealand, 2017.

18. De Klein, C.A.M.; Monaghan, R.M.; Alfaro, M.; Gourley, C.J.P.; Oenema, O.; Powell, J.M. Nitrogen performance indicators for dairy production systems. Soil Res. 2017, 55, 479-488. [CrossRef]

19. Parsons, A.; Thornley, J.H.M.; Rasmussen, S.; Rowarth, J.S. Some clarification of the impacts of grassland intensification on food production, nitrogen release, greenhouse gas emissions and carbon sequestration: Using the example of New Zealand. CAB Reviews: Perspect. Agric., Vet. Sci., Nutr. Nat. Resour. 2016, 11. [CrossRef]

20. Foote, K.J.; Joy, M.K.; Death, R.G. New Zealand dairy farming: Milking our environment for all its worth. Environ. Manag. 2015, 56, 709-720. [CrossRef]

21. Jay, M. The political economy of a productivist agriculture: New Zealand dairy discourses. Food Policy 2007, 32, 266-279. [CrossRef]

22. Capuco, A.V.; Ellis, S.E.; Hale, S.A.; Long, E.; Erdman, R.A.; Zhao, X.; Paape, M.J. Lactation persistency: Insights from mammary cell proliferation studies. J. Animal Sci. 2003, 81, 18-31. [CrossRef]

23. Clark, D.A.; Phyn, C.V.; Tong, M.J.; Collis, S.J.; Dalley, D.E. A systems comparison of once- versus twice-daily milking of pastured dairy cows. J. Dairy Sci. 2006, 89, 1854-1862. [CrossRef] 
24. Edwards, J.P. Comparison of milk production and herd characteristics in New Zealand herds milked once or twice a day. Anim. Prod. Sci. 2018. [CrossRef]

25. Lynch, G.A.; Hunt, M.E.; MacKenzie, D.D.S. The effects of once daily milking as a management practice in late lactation. Proc. N. Z. Soc. Anim. Prod. 1991, 51, 191-195.

26. Bewsell, D.; Clark, D.A.; Dalley, D.E. Understanding motivations to adopt once-a-day milking amongst New Zealand dairy farmers. J. Agric. Educ. Ext. 2008, 14, 69-80. [CrossRef]

27. Stelwagen, K.; Phyn, C.V.C.; Davis, S.R.; Guinard-Flament, J.; Pomiès, D.; Roche, J.R.; Kay, J.K. Invited review: Reduced milking frequency: Milk production and management implications. J. Dairy Sci. 2013, 96, 3401-3413. [CrossRef]

28. L'Huillier, P.J.; Thomson, N.A. Estimation of herbage mass in ryegrass/white clover dairy pastures. Proc. N. Z. Grassl. Assoc. 1988, 41, 117-122.

29. Baker, R.D. Estimating herbage intake from animal performance. In Herbage Intake Handbook, 2nd ed.; British Grassland Society: London, UK, 2004; p. 191.

30. Corson, D.C.; Waghorn, G.C.; Ulyatt, M.J.; Lee, J. NIRS: Forage analysis and livestock feeding. Proc. N. Z. Grassl. Assoc. 1999, 61, 127-132.

31. Arunvipas, P.; Van Leeuwen, J.A.; Dohoo, I.R.; Keefe, G.P. Evaluation of the reliability and repeatability of automated milk urea nitrogen testing. Can. J. Vet. Sci. 2003, 67, 60-63.

32. Macdonald, K.A.; Macmillan, K.L. Condition score and liveweight in Jersey and Friesian cows. Proc. Ruakura Farmers Conf. 1993, 45, 47-50.

33. Macciotta, N.P.P.; Vicario, D.; Cappio-Borlino, A. Detection of different shapes of lactation curve for milk yield in dairy cattle by empirical mathematical models. J. Dairy Sci. 2005, 88, 1178-1191. [CrossRef]

34. Silvestre, A.M.; Petim-Batista, F.; Colaço, J. The accuracy of seven mathematical functions in modeling dairy cattle from lactation curves based on test-day records from varying sample schemes. J. Dairy Sci. 2006, 89, 1813-1821. [CrossRef]

35. Jarrige, R.; Demarquilly, C.; Dulphy, J.P.; Hoden, A.; Robelin, J.; Beranger, C.; Geay, Y.; Journet, M.; Malterre, C.; Micol, D.; et al. The INRA "fill unit" system for predicting the voluntary intake of forage-based diets in ruminants: A review. J. Anim. Sci. 1986, 63, 1737-1758. [CrossRef]

36. Berry, D.P.; Veerkamp, R.F.; Dillon, P. Phenotypic profiles for body weight, body condition score, energy intake, and energy balance across different parities and concentrate feeding levels. Livest. Sci. 2006, 104, 1-12. [CrossRef]

37. Spanghero, M.; Kowalski, Z.M. Critical analysis of $\mathrm{N}$ balance experiments with lactating cows. Livest. Prod. Sci. 1997, 52, 113-122. [CrossRef]

38. Huhtanen, P.; Cabezas-Garcia, E.H.; Krizsan, S.J.; Shingfield, K.J. Evaluation of between-cow variation in milk urea and rumen ammonia nitrogen concentrations and the association with nitrogen utilization and diet digestibility in lactating cows. J. Dairy Sci. 2015, 98, 3182-3196. [CrossRef]

39. Peyraud, J.L.; Vérité, R.; Delaby, L. Nitrogen excretion by dairy cows: Effect of the diet and of the level of production. Fourrages. 1995, 142, 131-144.

40. Reed, K.F.; Moraes, L.E.; Casper, D.P.; Kebreab, E. Predicting nitrogen excretion from cattle. J. Dairy Sci. 2015, 98, 3025-3035. [CrossRef] [PubMed]

41. Lapierre, H.; Berthiaume, R.; Raggio, G.; Thivierge, M.C.; Doepel, L.; Pacheco, D.; Dubreuil, P.; Lobley, G.E. The route of absorbed nitrogen into milk protein. Anim. Sci. 2005, 80, 11-22. [CrossRef]

42. Daniel, J.B.; Friggens, N.C.; Van Laar, H.; Ferris, C.P.; Sauvant, D. A method to estimate cow potential and subsequent responses to energy and protein supply according to stage of lactation. J. Dairy Sci. 2017, 100, 3641-3657. [CrossRef] [PubMed]

43. Spek, J.W.; Dijkstra, J.; Van Duinkerken, G.; Bannink, A. A review of factors influencing milk urea concentration and its relationship with urinary urea excretion in lactating dairy cattle. J. Agricult. Sci. 2013, 151, 407-423. [CrossRef]

44. Friggens, N.C.; Rasmussen, M.D. Milk quality assessment in automatic milking systems: Accounting for the effects of variable intervals between milkings on milk composition. Livest. Prod. Sci. 2001, 73, 45-54. [CrossRef]

45. Nielsen, N.I.; Larsen, T.; Bjerring, M.; Ingvartsen, K.L. Quarter health, milking interval, and sampling time during milking affect the concentration of milk constituents. J. Dairy Sci. 2005, 88, 3186-3200. [CrossRef] 
46. Barros, T.; Quaassdorff, M.A.; Aguerre, M.J.; Olmos Colmenero, J.J.; Bertics, S.J.; Crump, P.M.; Wattiaux, M.A. Effects of dietary crude protein concentration on late-lactation dairy cow performance and indicators of nitrogen utilization. J. Dairy Sci. 2017, 100, 5434-5448. [CrossRef] [PubMed]

47. Mutsvangwa, T.; Davies, K.L.; McKinnon, J.J.; Christensen, D.A. Effects of dietary crude protein and rumen-degradable protein concentrations on urea recycling, nitrogen balance, omasal nutrient flow, and milk production in dairy cows. J. Dairy Sci. 2016, 99, 6298-6310. [CrossRef] [PubMed]

48. De Campeneere, S.; De Brabander, D.L.; Vanacker, J.M. Milk urea concentration as affected by the roughage type offered to dairy cattle. Livest. Sci. 2006, 103, 30-39. [CrossRef]

49. Hynes, D.N.; Stergiadis, S.; Gordon, A.; Yan, T. Effects of crude protein level in concentrate supplements on animal performance and nitrogen utilization of lactating dairy cows fed fresh-cut perennial grass. J. Dairy Sci. 2016, 99, 8111-8120. [CrossRef]

50. Trevaskis, L.M.; Fulkerson, W.J. The relationship between various animal and management factors and milk urea, and its association with reproductive performance of dairy cows grazing pasture. Livest. Prod. Sci. 1999, 57, 255-265. [CrossRef]

(C) 2020 by the authors. Licensee MDPI, Basel, Switzerland. This article is an open access article distributed under the terms and conditions of the Creative Commons Attribution (CC BY) license (http://creativecommons.org/licenses/by/4.0/). 